\title{
Potency of silicon in reducing cadmium toxicity in Cempo Merah rice
}

\begin{abstract}
Rita Ariyana Nur Khasanah ${ }^{1,2}$, Diah Rachmawati ${ }^{2 *}$
${ }^{1}$ Faculty of Science and Technology, UIN Walisongo Semarang, 50181- Indonesia

${ }^{2}$ Department of Tropical Biology, Faculty of Biology, Universitas Gadjah Mada, Yogyakarta, 55281- Indonesia

Abstract

Cadmium $(\mathrm{Cd})$ is a toxic and harmful heavy metal that contaminates agricultural soil when released into the environment. The beneficial element silicon ( $\mathrm{Si}$ ) can be used to reduce Cd stress. However, the mechanism for reducing Cd toxicity in Cempo Merah rice remains unclear. In this study, we conducted an experiment to determine the required potency of $\mathrm{Si}$ for reducing $\mathrm{Cd}$ toxicity in the plant. We used a randomized design with two factorials, i.e., calcium silicate and cadmium sulfate at various concentrations $\left(0 \mathrm{mg} \mathrm{kg}^{-1}, 50 \mathrm{mg} \mathrm{kg}^{-1}\right.$, and $\left.100 \mathrm{mg} \mathrm{kg}^{-1}\right)$ with three replicates. The plants were maintained for 8 weeks. The measured parameters included the $\mathrm{Cd}, \mathrm{Si}$, and malondialdehyde (MDA) contents, superoxide dismutase (SOD) activity, and plant biomass. Using microscopy, we observed the anatomical root structure, including the thicknesses of the exodermis, sclerenchyma, and endodermis cell walls. The experimental results showed that an excess of $\mathrm{Cd}$ inhibited plant growth and increased the MDA content. Increased plant tolerance against the effect of $\mathrm{Cd}$ is required for their growth and survival in overcoming the negative impact of $\mathrm{Cd}$ exposure. As silicon is involved in the formation by roots of an apoplast barrier to limit Cd uptake, a combination of $\mathrm{Cd}$ and $\mathrm{Si}$ treatment in plants was found to produce lower $\mathrm{Cd}$ contents in the plant shoots and a minimum $\mathrm{Cd}$ translocation factor. The addition of $\mathrm{Si}$ was also observed to increase the SOD activity in plants under $\mathrm{Cd}$ stress. Therefore, $\mathrm{Si}$ is suggested to have potency in reducing Cd toxicity in Cempo Merah rice and increasing rice growth.
\end{abstract}

Keywords: Cadmium, Growth, Cempo Merah rice, Silicon, Toxicity

\section{How to cite this:}

Khasanah RAN and Rachmawati D, 2020. Potency of silicon in reducing cadmium toxicity in Cempo Merah rice. Asian J. Agric. Biol. 8(4): 405-412. DOI: https://doi.org/10.35495/ajab.2019.12.571

This is an Open Access article distributed under the terms of the Creative Commons Attribution 3.0 License. (https://creativecommons.org/licenses/by/3.0), which permits unrestricted use, distribution, and reproduction in any medium, provided the original work is properly cited.

\section{Introduction}

Agricultural soil contamination due to the accumulation of cadmium $(\mathrm{Cd})$ causes toxicity in many crops (Nazar et al., 2012). Excessive use of phosphate fertilizer and industrial activities lead to $\mathrm{Cd}$ contamination in paddy soils and reductions in crop yields (Roberts, 2014). In non-contaminated soil, the Cd concentration is typically less than $0.5 \mathrm{ppm}$ (Nazar et al., 2012), but the concentration may increase due to natural and anthropogenic factors. In high concentrations, Cd inhibits plant growth (Nazar et al., 2012). Liu et al. (2013) reported that the Cd uptake in sorghum grown in Cd-contaminated soil $\left(50 \mathrm{mg} \mathrm{kg}^{-1}\right.$ 
and $100 \mathrm{mg} \mathrm{kg}^{-1}$ of soil) significantly suppressed growth. Other studies have reported that $\mathrm{Cd}$ exposure decreased the growth of peas (Pisum sativum L.) exposed for a period of 20 days (Hattab et al., 2009) and Lemna polyrrhiza L exposed for a period of 30 days (John et al., 2007). With a longer exposure period, $\mathrm{Cd}$ can lead to cell death (Benavides et al., 2005). This growth inhibition is associated with decreased chlorophyll synthesis and the rate of photosynthesis. Hédiji et al. (2010) found there to be a significant decrease of carotenoids and chlorophyll in old tomato leaves exposed to $\mathrm{Cd}$ for 90 days.

Another effect of $\mathrm{Cd}$ is lipid peroxidation, which is characterized by a high malondyaldehyde (MDA) level (Guo et al., 2017). A Cd-exposed plant experiences oxidative stress, and a consequent increase in reactive oxygen species (ROS) molecules, such as superoxide $\left(\cdot \bullet_{2}{ }^{-}\right)$, hydrogen peroxide $\left(\mathrm{H}_{2} \mathrm{O}_{2}\right)$, and hydroxyl radicals $(\bullet \mathrm{OH})$ (Gill and Tuteja, 2010). $\mathrm{Cd}$ is a non-redox heavy metal, that is, it is only indirectly involved in redox reactions, but it can induce oxidative stress by interrupting antioxidant systems and some metabolic processes. The high ROS molecule can have an oxide lipid membrane consisting of poly unsaturated fatty acid, which will easily decompose to MDA (Gill and Tuteja, 2010). Therefore, MDA is often used as an oxidative stress marker.

Certain plants have a protection mechanism when exposed to a heavy metal, such as the ability to deploy an antioxidant defense system or to restrict metal translocation into their shoots by forming an apoplastic barrier in the roots (Benavides et al., 2005; Lux et al., 2011). Superoxide dismutase (SOD) is an antioxidant enzyme that has a role as a first line of defense, whereby it converts the more reactive superoxide $\left(\cdot \mathrm{O}_{2}^{-}\right)$molecule into the less reactive hydrogen peroxide $\left(\mathrm{H}_{2} \mathrm{O}_{2}\right)$ molecule (Gill and Tuteja, 2010). Among other plant defense strategies, silicon (Si) is effective in reducing Cd toxicity (Liang et al, 2007; Tang et al., 2015; Farooq et al., 2016). Si is beneficial to plants and has become essential to some plants, especially rice. Reducing mechanisms can work via both enzymatic and non-enzymatic antioxidant stimulation, and that of $\mathrm{Si}$ works by stimulating SOD activity (Tang et al., 2015). Si also has role in the formation of root apoplastic barriers to reduce Cd uptake (Liang et al., 2007).

In this study, we used Cempo Merah rice (Oryza sativa L.), an original cultivar from Sleman, Yogyakarta, Indonesia. The seed from this cultivar is fluffier and has higher in vitamin and mineral contents than other cultivars (Kristamtini and Purwaningsih, 2009). Rice growth requires the support of an irrigation system, and heavy-metal contamination is unavoidable. The mechanism by which $\mathrm{Si}$ reduces $\mathrm{Cd}$ toxicity in this plant remains unclear. The goal of this study was to conduct an experiment to determine the potential of silicon in reducing the toxicity of $\mathrm{Cd}$.

\section{Material and Methods}

The experiment was conducted in the greenhouse of the Faculty of Agriculture, Universitas Gadjah Mada, Indonesia, with calcium silicate $\left(\mathrm{CaSiO}_{3}\right.$, Sigma Aldrich) and cadmium sulfate $\left(3 \mathrm{CdSO}_{4} .8 \mathrm{H}_{2} \mathrm{O}\right)$ as the $\mathrm{Si}$ and $\mathrm{Cd}$ sources. The growth medium was silt loam soil, the properties of which are listed in Table 1 . We used a randomized design with two factorials, i.e., $\mathrm{CaSiO}_{3}$ and $3 \mathrm{CdSO}_{4} .8 \mathrm{H}_{2} \mathrm{O}$ at concentrations of $0 \mathrm{mg}$ $\mathrm{kg}^{-1}, 50 \mathrm{mg} \mathrm{kg}^{-1}$, and $100 \mathrm{mg} \mathrm{kg}^{-1}$. Calcium silicate was added to the soil during the preparation stage. The selected 'Cempo Merah' rice seedlings were planted in polybags after 2 weeks of germination. The watering volume was adjusted to the water holding capacity. $\mathrm{Cd}$ was applied to the soil three times, on the $18^{\text {th }}, 27^{\text {th }}$, and $36^{\text {th }}$ day after the seedlings were planted in the polybags, and the plants were maintained for 8 weeks. We measured the plant biomass (shoots and roots dry weights) to determine the plant growth.

Table-1. Soil properties

\begin{tabular}{|c|c|}
\hline Properties & Value \\
\hline Texture & Silt loam soil \\
\hline Sand & $38 \%$ \\
\hline Silt & $55 \%$ \\
\hline Clay & $7 \%$ \\
\hline C-organic & $0.56 \%$ \\
\hline $\mathrm{pH}$ & 6.82 \\
\hline Humidity & $80-90 \%$ \\
\hline Organic matter & $1.37 \%$ \\
\hline Total N & $0.12 \%$ \\
\hline Available $\mathrm{N}$ & $107.28 \mathrm{ppm}$ \\
\hline Total P & $0.04 \%$ \\
\hline Available P & $18.04 \mathrm{ppm}$ \\
\hline Total $\mathrm{K}$ & $0.05 \%$ \\
\hline Available $\mathrm{K}$ & $0.72 \mathrm{me} .100 \mathrm{~g}^{-1}$ \\
\hline Cation Exchange Capacity & $24.07 \mathrm{me}^{2} 100 \mathrm{~g} \mathrm{~g}^{-1}$ \\
\hline Cd content & $<0.01 \mathrm{ppm}$ \\
\hline $\mathrm{SiO}_{2}$ content & $1921.69 \mathrm{ppm}$ \\
\hline
\end{tabular}

The measurements of the Cd content in the shoots, roots, and soil were performed using a modified method from that of Hédiji et al. (2010). The Cd 
content was determined using flame atomic absorptions spectrometry (ContrAA ${ }^{\circledR} 300$ Analytic Jena). The Cd translocation factor was obtained by measuring the ratio of the $\mathrm{Cd}$ contents in the shoots and roots. Using a spectrophotometer (UV-1800 Shimadzu) at $\lambda 650 \mathrm{~nm}$, we adopted a modified method from that of Wei-min et al. (2005) to measure the Si contents of the shoots and roots. The MDA content was also measured using a spectrophotometer (Genesis UV- Scanning Thermo-Scientific) at $\lambda 532$ and $600 \mathrm{~nm}$ and the thiobarbituric acid method with some modifications (Velikova et al., 2000).

We measured the SOD activity using a method modified from that of Shi et al. (2005) and a nitroblue tetrazolium (NBT) reagent. Increases in the SOD activity of the sample were indicated by a decrease in the formazan-blue color intensity. One unit of SOD activity in the extract was defined as that causing a $50 \%$ inhibition of NBT photo-reduction (Beauchamp and Fridovich, 1971). We prepared a cross section of the root $2 \mathrm{~cm}$ from the base using the embedding method (Ruzin, 1999). The anatomical structure of the root, including the thicknesses of the exodermis, sclerenchyma, and endodermis cell walls, was observed using a binocular light microscope (BOECO BM-180). All the presented data are means obtained from three replicate measurements. The data were analyzed using analysis of variance and SPPS Statistic 19 software. We used Duncan's test to evaluate the importance of the discrepancy among measures with $\mathrm{p}$ values $<0.05$.

\section{Results and Discussion}

$\mathrm{Cd}$ stress has a negative impact on the life cycle of plants by suppressing their growth. Researchers have reported that a high Cd uptake inhibits plant growth in a variety of species, including for example tomato seedlings (Hédiji et al., 2010), Pisum sativum L. (Hattab et al., 2009), and Lemna polyrrhiza L. (John et al., 2007). The growth of three sorghum cultivars was reported to be significantly reduced by $\mathrm{Cd}$ stress (Liu et al., 2011). The growth parameter in this study was measured based on the plant biomass. Excess Cd was found to significantly reduce the dry weights of shoots and roots (Table 2), and the addition of exogenous $\mathrm{Si}$ to Cd-exposed plants significantly increased these weights.

The results indicate that $\mathrm{Cd}$ reduced the biomass of Cempo Merah rice (Table 2). The growth inhibition in $\mathrm{Cd}$-stressed plants may occur because $\mathrm{Cd}$ affects the plant's metabolism by interfering with the water and mineral uptakes by its roots (Nazar et al., 2012). Because of its high mobility, the $\mathrm{Cd}^{2+}$ ion is easily absorbed and transported to aerial organs (Benavides et al., 2005).

Table-2. Dry weights of shoots and roots of Cempo Merah rice treated with $\mathrm{Si}$ and $\mathrm{Cd}$

\begin{tabular}{|c|c|c|}
\hline \multirow{2}{*}{ Treatment } & \multicolumn{2}{|c|}{ Dry weight (g) } \\
\cline { 2 - 3 } & Shoots & Roots \\
\hline Si 0 Cd 0 (Control) & $12.76 \pm 0.36^{\mathrm{d}}$ & $1.87 \pm 0.21^{\mathrm{cd}}$ \\
\hline Si 0 Cd 50 & $11.18 \pm 0.69^{\mathrm{b}}$ & $1.54 \pm 0.07^{\mathrm{b}}$ \\
\hline Si 0 Cd 100 & $10.22 \pm 0.12^{\mathrm{a}}$ & $1.05 \pm 0.06^{\mathrm{a}}$ \\
\hline Si 50 Cd 0 & $13.75 \pm 0.19^{\mathrm{e}}$ & $1.96 \pm 0.08^{\mathrm{de}}$ \\
\hline Si 50 Cd 50 & $12.93 \pm 0.24^{\mathrm{d}}$ & $1.70 \pm 0.06^{\mathrm{bc}}$ \\
\hline Si 50 Cd 100 & $11.94 \pm 0.27^{\mathrm{c}}$ & $1.58 \pm 0.05^{\mathrm{b}}$ \\
\hline Si 100 Cd 0 & $14.17 \pm 0.44^{\mathrm{e}}$ & $2.10 \pm 0.08^{\mathrm{e}}$ \\
\hline Si 100 Cd 50 & $13.73 \pm 0.16^{\mathrm{e}}$ & $1.90 \pm 0.10^{\mathrm{d}}$ \\
\hline Si 100 Cd 100 & $12.97 \pm 0.23^{\mathrm{d}}$ & $1.64 \pm 0.11^{\mathrm{b}}$ \\
\hline Interaction of Si X Cd & + & + \\
\hline
\end{tabular}

Numbers on columns followed by the different letters indicate a significant difference based on Duncan's test $(\mathrm{p}<0.05)$. The $(+)$ symbol indicates interaction between $\mathrm{Si}$ and $\mathrm{Cd}$.

This ion does not have its own transporter, however, so it must compete with other ions for the same transporter, such as the ZIP family, NRAMP, and $\mathrm{Ca}^{2+}$ channel (Gao et al., 2016). For example, excess Cd was found to inhibit nitrate and $\mathrm{K}^{+}$ion uptakes in wheat (Triticum durum) seedlings (Veselov et al., 2003) and to affect the distributions of K, Fe, Zn, Mn and $\mathrm{Mg}$ in Iris lacteal (Guo et al., 2017). Niazy and Fouda (2016) studied the role of Si in alleviating the effect of $\mathrm{Cd}$ in lettuce (Lactuca sativa L.) The application of Si (100 mg kg-1 and $150 \mathrm{mg} \mathrm{kg}^{-1}$ of soil) was found to increase the dry weight of plants grown in Cd-contaminated soil with $\mathrm{Cd}$ concentrations of 5 $\mathrm{mg} \mathrm{kg}^{-1}, 10 \mathrm{mg} \mathrm{kg}^{-1}$, and $15 \mathrm{mg} \mathrm{kg}^{-1}$ of soil.

Silicon may have sufficient potency to reduce the negative effect of toxic heavy metals in plants, as described by Liang et al. (2007) and Bath et al. (2019). These mechanisms may include: 1) immobilizing the heavy-metal ion in growth media by increasing the soil $\mathrm{pH}$ and the co-precipitation of the toxic ion and $\mathrm{Si}$ in growth media; 2) stimulating both enzymatic and non-enzymatic antioxidant systems; 3) establishing the co-precipitation of toxic metal ions and $\mathrm{Si}$ in cell walls; and/or 4) stimulating compartmentation of the toxic ion in vacuoles by the formation of a phytochelatine-metal ion complex. Ma and Yamaji (2006) reported that $\mathrm{Si}$ could interact with several 
components in plant cell walls to form silica $\left(\mathrm{SiO}_{2}\right)$, which means that this substance promotes cell wall strength and rigidity, increases the mechanical support of the aerial parts of plants, and enhances plant growth.

In this study, we investigated the role of $\mathrm{Si}$ in reducing $\mathrm{Cd}$ toxicity in Cempo Merah rice based on the following parameters: the Cd contents in shoots, roots, and soil; the $\mathrm{Cd}$ translocation factor value; shoot and root $\mathrm{Si}$ contents, some biochemical parameters were also determined, including the MDA level and SOD activity, as well as the root anatomy with respect to the thickening of cell walls, which has been suggested as having a role in the Cd-blocking mechanism.

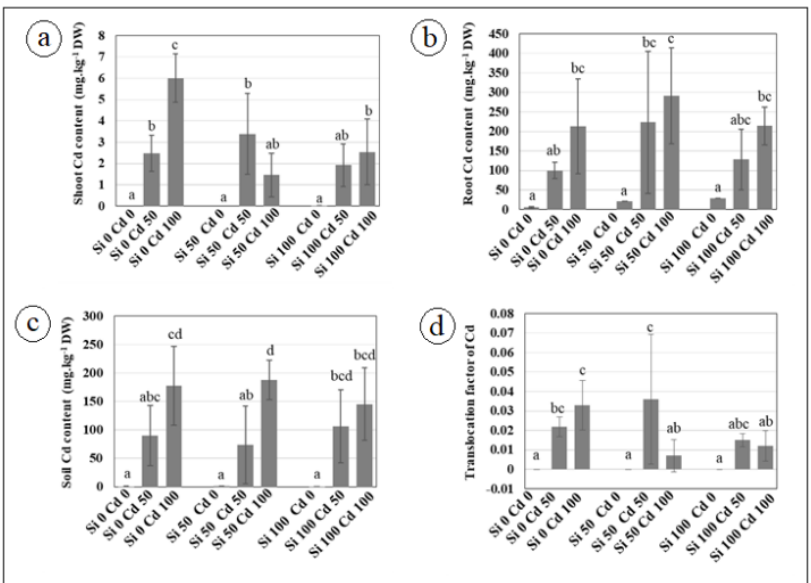

Figure 1. Cd contents in: (a) shoots and (b) roots and (c) soil treated with $\mathrm{Si}$ and $\mathrm{Cd}$; (d) $\mathrm{Cd}$ translocation factor values in plants. According to the results of Duncan's test, bars with different letters indicate significant differences at $p<0.05$.

Figures 1a-1c show the Cd uptake and translocation into plants based on the Cd contents of the shoots, roots, and soil. The shoots of plants treated with $\mathrm{Cd}$ (100 $\mathrm{mg} \mathrm{kg}^{-1}$ ) showed the highest Cd contents (Figure 1a) and this content was lower in plants treated with a combination of $\mathrm{Cd}$ and $\mathrm{Si}$. The $\mathrm{Cd}$ content in the roots of the control, Si-treated, and Cd-treated plants (100 $\mathrm{mg} \mathrm{kg}{ }^{-1}$ ) were significantly different (Figure 1b), however, the $\mathrm{Cd}$ contents in the roots of plant treated with only $\mathrm{Cd}$ and with the $\mathrm{Si}-\mathrm{Cd}$ combination showed no significant difference $(\mathrm{p}<0.05)$. A trend can be observed in which $\mathrm{Cd}$ had accumulated more in the roots of plants treated with the $\mathrm{Si}-\mathrm{Cd}$ combination than in those treated with $\mathrm{Cd}$ only. This result might be related to the lower $\mathrm{Cd}$ translocation factor in plants treated with the $\mathrm{Si}-\mathrm{Cd}$ combination than in plants treated only with Cd (Figure 1d). The Cd contents in soils of the control and Cd-treated plants were significantly different $(\mathrm{p}<0.05)$ (Figure $1 \mathrm{c})$, with the Cd content in plants treated with Si 50 Cd 100 being the highest.

The Cd content that accumulates in plants might be correlated with the stress level in Cempo Merah rice. The authors of one study reported that the application of exogenous $\mathrm{Si}$ into $\mathrm{Cd}$-exposed media decreased the Cd content in ramie (Tang et al., 2015). However, that finding seems to contradict the results obtained here. In our study, the addition of $\mathrm{Si}$ to Cd-stressed plants resulted in higher $\mathrm{Cd}$ contents in roots than those to which Si had not been added (Figure 1b). The high accumulation of $\mathrm{Cd}$ in the roots might have occurred due to the internal role of $\mathrm{Si}$ in blocking the $\mathrm{Cd}$ apoplast pathways (Liang et al., 2005). Si treatment could decrease the $\mathrm{Cd}$ translocation factor in $\mathrm{Cd}$ stressed plants and limit the $\mathrm{Cd}$ accumulation in shoots (Figures 1d and 1a). Tripathi et al. (2012) and Shi et al. (2015) investigated the role of $\mathrm{Si}$ in reducing the $\mathrm{Cd}$ contents in the shoots of $\mathrm{Cd}$-exposed maize and rice. In addition, the protective role of $\mathrm{Si}$ in limiting the $\mathrm{Cd}$ translocation ability in ramie was reported by Tang et al. (2015). Liu et al. (2013) noted that silicon could accumulate in cell walls. The co-deposition of $\mathrm{Si}$ and $\mathrm{Cd}$ in cell walls might explain the limitation on the uptake of the Cd ion (Liu et al., 2013). Vaculík et al. (2012) also reported that Si could enhance the binding of $\mathrm{Cd}$ to the apoplasmic fraction in maize. Thus, it is possible that more $\mathrm{Cd}$ had accumulated in the roots of the rice treated with $\mathrm{Si}$.

The Si contents in the shoots and roots fluctuated (Figure 2). The Si content in the shoots of plants treated with $\mathrm{Cd}$ showed a significant difference from those with other treatments $(\mathrm{p}<0.05)$ (Figure 2a). However, unexpectedly, the Si content of shoots in the control plants were the highest. The Si contents of the roots showed no significant difference among the treated plants, except for those treated with $\mathrm{Si}$ (50 mg. $\mathrm{kg}^{-1}$ ) (Figure 2b). The $\mathrm{Si}$ content in plants fluctuated due to the Si uptake by roots having been influenced by the level of abundantly available $\mathrm{Si}$ already present in the paddy soil. In addition, because rice is $\mathrm{Si}$ accumulator, each individual plant has a different Si uptake ability. The addition of exogenous $\mathrm{Si}$ into the soil thus tended to increase the Si content in the rice, which served to reduce the negative effects of $\mathrm{Cd}$ in Cempo Merah rice. 


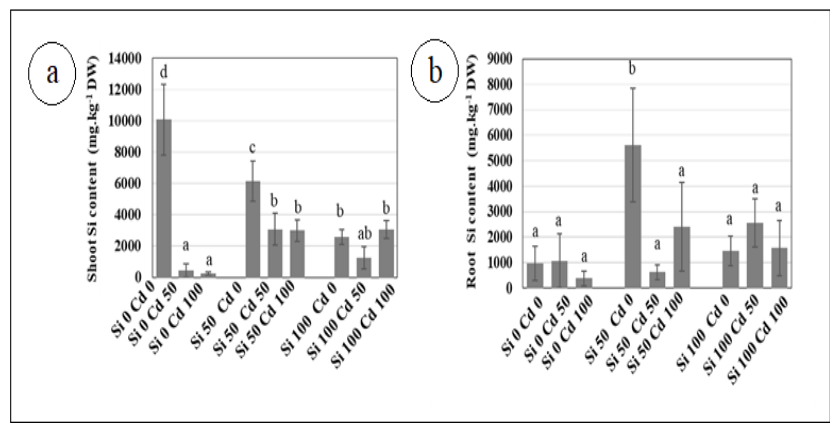

Figure 2. Si contents in: (a) roots and (b) shoots of plants treated with $\mathrm{Si}$ and $\mathrm{Cd}$. According to Duncan's test, bars with different letters differ significantly at $p<0.05$.

ROS molecules are transiently generated in plant cells during photosynthesis and cellular respiration, but their production will increase as an indirect consequence of heavy-metal toxicity (Gill and Tuteja, 2010; Stańczyk et al., 2005). Despite being an integral part of signal transduction and essential for intercellular communication, when produced in high quantities, they damage proteins, lipids, and nucleic acid, which ultimately causes oxidative stress. The $\mathrm{Cd}^{2+}$ ion is a non-redox heavy metal that is indirectly involved in redox reactions (Hossain et al., 2012). Thus, $\mathrm{Cd}$ contributes to the stress of plants and MDA is one of the important lipid peroxidation products.

The experimental results showed that excess $\mathrm{Cd}$ tended to increase the MDA contents (Figure 3a), but the addition of exogenous $\mathrm{Si}$ to $\mathrm{Cd}$-exposed plants significantly decreased their MDA contents $(\mathrm{p}<0.05)$. Plant treated with Cd (100) exhibited the highest MDA content, whereas plants treated with the Si (100) and $\mathrm{Cd}$ (50) combination exhibited the lowest MDA content. Many studies have reported that $\mathrm{Cd}$ stress increases the MDA content in various species, including for example Iris lactea L. (Guo et al., 2017) and Populus canescens (Dai et al., 2012). The addition of $\mathrm{Si}$ has been suggested to protect rice by reducing the MDA content (Figure 3a), and this role has been observed in Cd-exposed rice and ramie (Tripathi et al., 2012; Tang et al., 2015).

The main function of SOD is to scavenge ROS molecules to reduce the impact of $\mathrm{Cd}$ toxicity. Plants treated with $\mathrm{Cd}$ showed increased SOD activity (Figure 3b). SOD is an antioxidant enzyme that has crucial role as the first line of defense in scavenging ROS molecules by converting the superoxide radical $\left(\cdot \mathrm{O}_{2}{ }^{-}\right)$into hydrogen peroxide $\left(\mathrm{H}_{2} \mathrm{O}_{2}\right)$, a moderately reactive molecule (Gill and Tuteja 2010; Stańczyk et al., 2005).

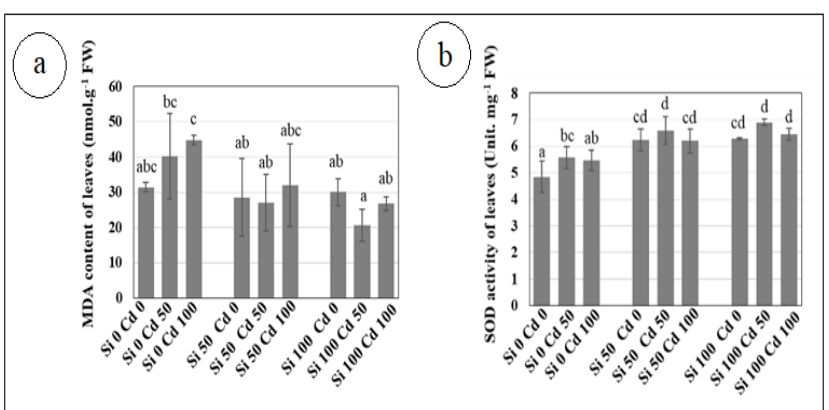

Figure 3. (a) MDA levels and (b) SOD activities in leaves of red rice (Oryza sativ L. 'Cempo Merah') treated with Si and Cd. According to Duncan's test, bars with different letters differ significantly at $p<$ 0.05 .

Cd treatment increased the SOD activity of the plant for its own defense. Exogenous Si application in Cdexposed plants resulted in an increase in SOD activity, with the highest SOD activity observed in plants treated with Si (100) and Cd (50) (Figure 3b). Silicon has been reported by Tang et al. (2015) to increase SOD activity in supporting the defense of plants under Cd stress.

Table-3. Exodermis, sclerenchyma, and endodermis cell walls, and root diameters of 'Cempo Merah' red rice with Si and Cd treatments

\begin{tabular}{|l|c|c|c|}
\hline \multirow{2}{*}{ Treatments } & \multicolumn{3}{|c|}{ Thickness of cell walls $(\boldsymbol{\mu m})$} \\
\cline { 2 - 4 } & Exodermis & Sclerenchyma & Endodermis \\
\hline Si 0 Cd 0 & $1.43 \pm 0.03^{\mathrm{a}}$ & $2.26 \pm 0.19^{\mathrm{abc}}$ & $3.02 \pm 0.99^{\mathrm{a}}$ \\
\hline Si 0 Cd 50 & $1.51 \pm 0.05^{\mathrm{ab}}$ & $2.04 \pm 0.16^{\mathrm{ab}}$ & $3.30 \pm 0.12^{\mathrm{ab}}$ \\
\hline Si 0 Cd 100 & $1.41 \pm 0.02^{\mathrm{a}}$ & $1.68 \pm 0.31^{\mathrm{a}}$ & $3.02 \pm 0.23^{\mathrm{a}}$ \\
\hline Si 50 Cd 0 & $1.63 \pm 0.07^{\mathrm{bcd}}$ & $2.77 \pm 0.26^{\mathrm{bc}}$ & $3.10 \pm 0.21^{\mathrm{a}}$ \\
\hline Si 50 Cd 50 & $1.70 \pm 0.09^{\mathrm{cd}}$ & $2.84 \pm 0.37^{\mathrm{c}}$ & $3.30 \pm 0.31^{\mathrm{ab}}$ \\
\hline Si 50 Cd 100 & $1.74 \pm 0.18^{\mathrm{cd}}$ & $2.93 \pm 0.07^{\mathrm{c}}$ & $3.36 \pm 0.07^{\mathrm{ab}}$ \\
\hline Si 100 Cd 0 & $1.80 \pm 0.07^{\mathrm{d}}$ & $2.96 \pm 1.03^{\mathrm{c}}$ & $4.06 \pm 0.36^{\mathrm{b}}$ \\
\hline Si 100 Cd 50 & $1.63 \pm 0.06^{\mathrm{bc}}$ & $3.05 \pm 0.34^{\mathrm{c}}$ & $3.58 \pm 0.52^{\mathrm{ab}}$ \\
\hline Si 100 Cd 100 & $1.52 \pm 0.11^{\mathrm{ab}}$ & $2.52 \pm 0.04^{\mathrm{bc}}$ & $3.65 \pm 0.66^{\mathrm{ab}}$ \\
\hline $\begin{array}{l}\text { Interaction of } \\
\text { Si X Cd }\end{array}$ & + & & \\
\hline
\end{tabular}

Numbers in columns followed by the different letters show significant differences based on the Duncan's test ( $\mathrm{p}<0.05) .(+)$ interaction between $\mathrm{Si}$ and $\mathrm{Cd}$; (-) indicates no interaction between $\mathrm{Si}$ and $\mathrm{Cd}$. 


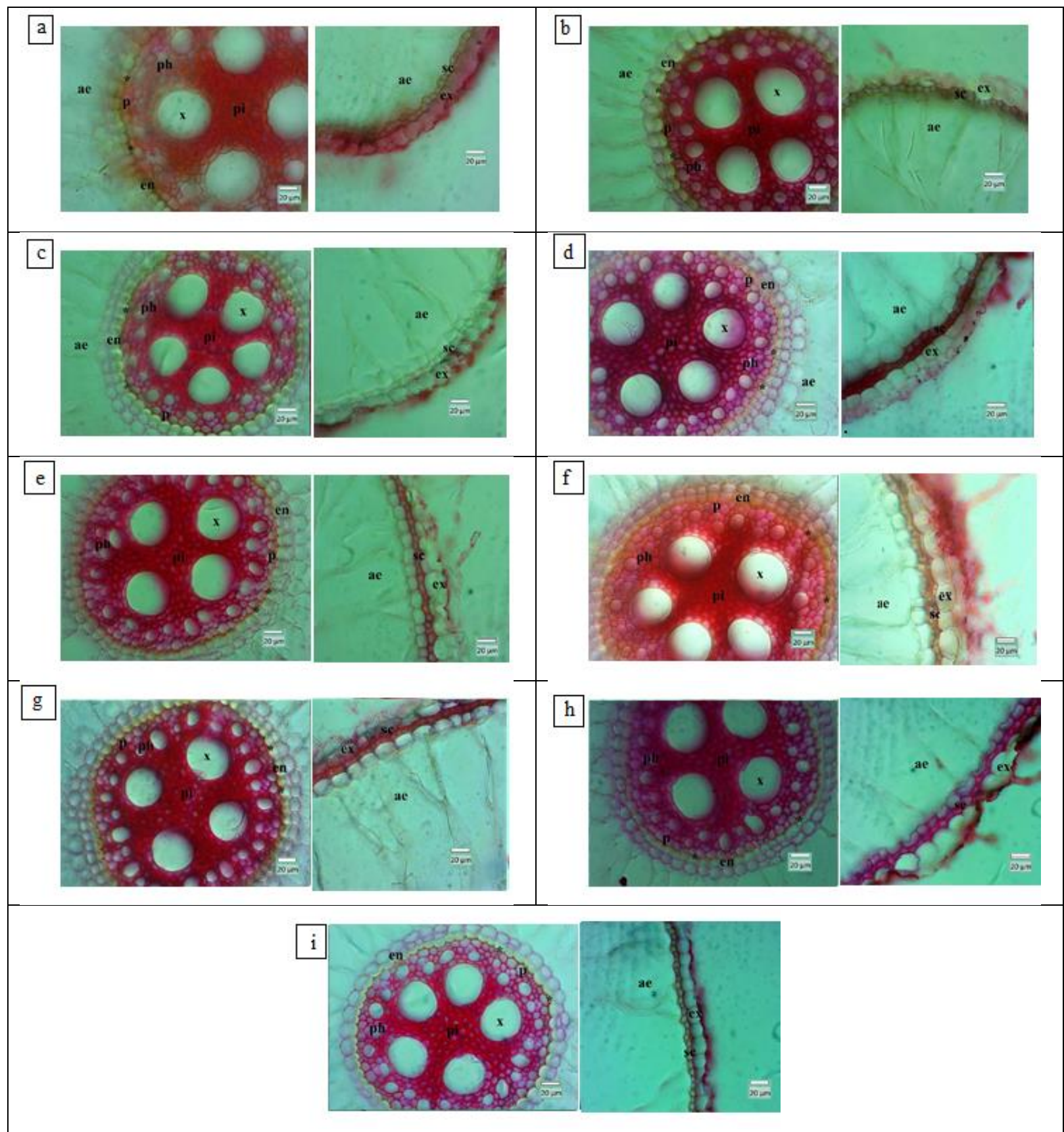

Figure 4. Root anatomical structure of rice plants treated with: (a) control, (b) Cd 50, (c) Cd 100, (d) $\mathrm{Si} \mathrm{50,}$ (e) Si 50 and Cd 50, (f) Si 50 and Cd 100, (g) Si 100, (h) Si 100 and Cd 50, and (i) Si 100 and Cd $100 \mathrm{mg} \mathrm{kg}^{-}$ 1. From left to right: stele and peripheral regions. Abbreviations: $x(x y l e m)$, ph (phloem), p (pericycle), en (endodermis), pi (pith), ae (aerenchyme), sc (sclerenchyme), and ex (exodermis). (*): U-type endodermic wall thickening. Bars: $20 \mu \mathrm{m}$.

Figure 4 shows transverse cross sections of rice roots. As we can see, thickening occurred in the cell walls of the endodermis, sclerenchyma, and exodermis of roots treated with $\mathrm{Si}$ and a combination of $\mathrm{Si}$ and $\mathrm{Cd}$. This descriptive analysis was confirmed by the measurement of the thicknesses of these cell walls
(Table 3).

The role of roots is to absorb water and nutrients, but they can also absorb undesirable compounds such as toxic metals. Although plants absorb $\mathrm{Cd}^{2+}$ ions through symplast and apoplast pathways, they also have tolerance mechanisms for limiting the 
translocation of $\mathrm{Cd}$ into their shoots. In the symplast pathway, the uptake of $\mathrm{Cd}$ is limited by $\mathrm{Cd}$ chelators known as phytochelatins, which play a $\mathrm{Cd}$ detoxification role in plants by chelating and sequestering Cd ions in vacuoles (Gao et al., 2016). In the apoplast pathway, $\mathrm{Cd}$ uptake is restricted by the thickening of the exodermis, endodermis, and sclerenchyma cell walls of the roots (Lux et al., 2011). The exodermis and endodermis enable roots to establish and maintain selectivity with respect to ion uptakes.

The suberization of the cell walls of the exodermis and endodermis and the lignification of cell walls of the sclerenchyma are reported to result in an important barrier in the apoplast pathway and the means by which nutrient uptakes are controlled (Lux et al., 2011). The observed root anatomy in Cempo Merah rice treated only with $\mathrm{Si}$ and that treated with a combination of $\mathrm{Si}$ and $\mathrm{Cd}$ showed thickenings of the cell walls of the roots' endodermis, sclerenchyma, and exodermis (Figure 4, Table 3). The addition of $\mathrm{Si}$ is thought to increase the suberization and lignification activities of these cell walls. In maize roots, $\mathrm{Si}$ is reportedly deposited within the cell walls of the endodermis and pericycle, which seemed to serve as a tolerance mechanism in maize against $\mathrm{Cd}$ stress (Da Cunha and Nascimento, 2009). In this study, suberized and lignified rice roots enabled the plants to limit the Cd translocation from their roots to their shoots.

\section{Conclusion}

In conclusion, excess $\mathrm{Cd}$ in the soil was found to inhibit rice growth and increase the MDA content in Cempo Merah rice. To deal with the negative impacts of $\mathrm{Cd}$ exposure, plant tolerance to $\mathrm{Cd}$ must be increased to ensure its survival and growth. We suggest that silicon is involved in the formation of a root apoplast barrier that limits $\mathrm{Cd}$ uptake and increase SOD activity. Therefore, we suggest that $\mathrm{Si}$ has potency in reducing Cd toxicity in Oryza sativa L. Cempo Merah rice plants and increasing their growth.

Disclaimer: None.

Conflict of Interest: None.

Source of Funding: This study was funded by the Indonesia Endowment Fund for Education (LPDP) Research Grant.

\section{References}

Bath JA, Shivaraj SM, Singh P, Navadagi DB, Tripathi DK, Dash PK, Solanke AU, Sonah H and Deshmukh R, 2019. Role of silicon in mitigation of heavy metal stresses in crop plants. Plants. 8 (71): 1-20.

Beauchamp C and Fridovich I, 1971. Superoxide dismutase: improved assays and an assay applicable to acrylamide gels. Anal. Biochem. 44(1): 276-287.

Benavides MP, Gallego SM and Tomaro ML, 2005. Cadmium toxicity in plants. Braz. J. Plant Physiol. 17 (1): 21-34.

Da Cunha KPV and Nascimento CW, 2009. Silicon effects on metal tolerance and structural changes in maize (Zea mays L.) grown on a cadmium and zinc enriched soil. Water Air Soil Pollut. 197 (1): 323-330.

Dai H, Shan C, Lu C, Jia G,Wei A, Wenqing S and Yang T, 2012. Response of antioxidant enzymes in Populus canescens under cadmium stress. Pak. J. Bot. 44 (6): 1943-1949.

Farooq MA, Detterbeck A, Clemens S and Dietz KJ, 2016. Silicon-induced reversibility of cadmium toxicity in rice. J. Exp. Bot. 67 (11): 3573-3585.

Gao L, Chang J, Chen R, Li H, Lu H, Tao L and Xiong J, 2016. Comparison on cellular mechanisms of iron and cadmium accumulation in rice: prospects for cultivating Fe-rich but $\mathrm{Cd}$-free rice. Rice. 9 (39): $1-12$.

Gill SS and Tuteja N, 2010. Reactive oxygen species and antioxidant machinery in abiotic stress tolerance in crop plants. Plant Physiol. Biochem. 48(12): 909-930.

Guo Q, Meng L, Zhang Y, Mao P, Tian X, Li S and Zhang L, 2017. Antioxidative systems, metal ion homeostasis and cadmium distribution in Iris lactea exposed to cadmium Stress. Ecotoxicol. Environ. Safe. 139: 50-55.

Hattab S, Dridi B, Chouba L, Kheder MB and Bousetta H, 2009. Photosynthesis and growth responses of pea (Pisum sativum L.) under heavy metals stress. J. Environ. Sci. (China). 21(11): 1552-1556.

Hédiji H, Djebali W, Cabasson C, Maucourt M, Baldet P, Bertrand A, Zoghlami B, Deborde C, Moing A, Brouquisse R, Chaibi W and Gallusci P, 2010. Effects of long-term cadmium exposure on growth and metabolomic profile of tomato plants. Ecotoxicol. Environ. Saf. 73(8): 1965-1974. 
Hossain MA, Piyatida P, da Silva JA and Fujita M, 2012. Molecular mechanism of heavy metal toxicity and tolerance in plants: central role of glutathione in detoxification of reactive oxygen species and methylglyoxal and in heavy metal chelation. J. Bot. 1-37.

John R, Ahmad P, Gadgil K and Sharma S, 2007. Antioxidative response of Lemna polyrrhiza L. to cadmium stress. J. Environ. Biol. 28 (3): 583-589.

Kristamtini and Purwaningsih H, 2009. Potential of red rice development as Yogyakarta's germplasm. J. Lit. 28 (3): 88-95. (Indonesian)

Liang Y, Wanchun S, Zhu Y and Christie P, 2007. Mechanisms of silicon-mediated alleviation of abiotic stresses in higher plants: a review. Environ Pollut. 147 (2): 422-428.

Liang Y, Wong JWC and Wei L, 2005. Siliconmediated enhancement of cadmium tolerance in maize (Zea mays L.) grown in cadmium contaminated soil. Chemosphere. 58(4): 475-483.

Liu D, Kai-qi H, Jing-jing, M, Wei-wei Q, Xiu-ping W and Shu-pan Z, 2011. Effects of cadmium on the growth and physiological characteristics of sorghum plants. Afr. J. Biotechnol. 10 (70): 15770-15776.

Liu J, Ma J, He C, Li X, Zhang W, Xu F, Lin Y and Wang L, 2013. Inhibition of cadmium ion uptake in rice (Oryza sativa) cells by a wall-bound form of silicon. New Phytol. 200 (3): 691-699.

Lux A, Martinka M, Vaculík M and White PJ, 2011. Root responses to cadmium in the rhizosphere: A Review. J. Exp. Bot. 62 (1): 21-37.

Ma JF and Yamaji, 2006. Silicon uptake and accumulation in higher plants. Trends Plant Sci. 11 (8): 1-6.

Nazar R, Iqbal N, Masood A, Khan MIR, Syeed S and Khan NA, 2012. Cadmium toxicity in plants and role of mineral nutrients in its alleviation. Am. J. Plant Sci. 3(10):1476-1489.

Niazy MM and Fouda S, 2016. Reducing the risk of $\mathrm{Cd}$ in lettuce (Lactuca sativa L.) via silicon application. Egypt. J. Soil Sci. 56 (3): 489-501.

Roberts TL, 2014. Cadmium and phosphorous fertilizers: the issues and the science. Procedia Eng. 83: 52-59.

Ruzin SE, 1999. Plant microtechnique and microscopy. Oxford University Press. New York, USA.

Shi Q, Bao Z, Zhu Z, He Y, Qian Q and Yu J, 2005. Silicon-mediated alleviation of Mn toxicity in
Cucumis sativus in relation to activities of superoxide dismutase and ascorbate peroxidase. Phytochem. 66(13): 1551-1559.

Shi X, Zhang C, Wang H and Zhang F, 2015. Effect of $\mathrm{Si}$ on the distribution of $\mathrm{Cd}$ in rice seedlings. Plant Soil. 272(1-2): 53-60.

Stańczyk M, Gromadzińska, J and Wąsowicz W, 2005. Roles of reactive oxygen species and selected antioxidants in regulation of cellular metabolism. Int. J. Occup. Med. Environ. Health. 18(1):15-26.

Tang H, Liu Y, Gong X, Zeng G, Zheng B, Wang D, Sun Z, Zhou L and Zeng X, 2015. Effects of selenium and silicon on enhancing anti-oxidative capacity in ramie (Boehmeria nivea (L.) Gaud.) under cadmium stress. Environ. Sci. Pollut. Res. 22(13): 9999-10008.

Tripathi DK, Singh VP, Kumar D and Chauhan DK, 2012. Rice seedlings under cadmium stress: effect of silicon on growth, cadmium uptake, oxidative stress, antioxidant capacity and root and leaf structures. Chem. Ecol. 28 (3): 281-291.

Vaculík M, Landberg T, Greger M, Luxova' M, Stola'rikova' M and Lux A, 2012. Silicon modifies root anatomy, and uptake and subcellular distribution of cadmium in young maize plants. Ann. Bot. 110(2): 433-443.

Velikova V, Yordanov I and Edreva A, 2000. Oxidative stress and some antioxidant systems in acid rain-treated bean plants protective role of exogenous polyamines. Plant Sci. 151(1): 59-66.

Veselov D, Kudoyarova1 G, Symonyan $M$ and Veselov St, 2003. Effect of cadmium onion uptake, transpiration and cytokinin content in wheat seedlings. Bulg. J. Plant Physiol. 353-359.

Wei-min D, Ke-qin Z, Bin-wu D, Cheng-xiao S, Kang-le Z, Run C and Jie-yun Z, 2005. Rapid determination of silicon content in rice. Rice Sci. 12(2): 145-147.

\section{Contribution of Authors}

Khasanah RAN: Conceived idea, designed research methodology, data collection, data interpretation, statistical analysis, manuscript writing and manuscript final editing

Rachmawati D: Conceived idea, designed research methodology, manuscript writing, manuscript final reading and approval 